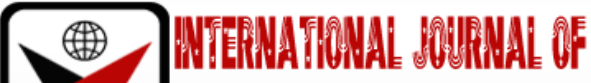

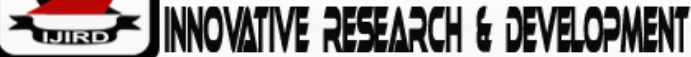

ISSN 2278-0211 (Online)

\section{Benefits of Quality Assurance and Control in Construction Industry}

\author{
ZulaiJarmai Baba-Girei \\ Senior Research Officer, Department of Building Research (BRD), \\ Nigerian Building and Road Research Institute (NBRRI), Nigeria \\ Esumobi Godfrey \\ M.Sc. Student, Department of Building, \\ University of Jos, Nigeria \\ Muhammad Mayaki \\ Architect Research, Department of Consultancy Services, \\ Icons Arkitektur-OCA, Nigeria \\ Ahmad Usman Naibi \\ Principal Architect, Department of Consultancy Services, \\ Icons Arkitektur-OCA, Nigeria \\ Elvis Chuku Ndame \\ Lecturer, Department of Building Department \\ University of Jos, Nigeria
}

\begin{abstract}
:
Quality assurance and control has been established by researchers to provide guidance for establishing an appropriate quality management procedure, in order to lower cost, increase productivity and customer's satisfaction, as well as market share in construction. This can assist construction industry to achieve successfully, their objectives, and ensure that all phases of construction projects consistently meet client's requirements. Basically, the objective of the study is to assess the level of quality assurance and control in construction through compliance evaluation and assessing the benefits and factors of implementing quality assurance and control on construction projects in Abuja and Environs. The research methodology adopted was an in-depth literature review and questionnaire administration while the data collected were subjected to descriptive statistical analysis through the application of percentage, frequency, mean and score. The findings have shown that construction firm's adherence and compliance to International Standard Organisation series is low. The benefits of adopting Quality assurance and control are to improve site management, enhance reputation for good design and proper effective planning. It also highlighted factors affecting quality assurance and control implementation to be incompatible tendering procedure, design complexity, poor performance of quality and low tendency for team work. Finally, the measures for improving quality standard are enforcement of quality standard by agency of government and regulatory bodies and provision of training service on quality assurance. The study also recommends that all stakeholders need to understand the importance of quality assurance and control standards and also inculcate them throughout the design productive phase of their projects.
\end{abstract}

Keywords: Construction, quality, assurance, control, management

\section{Introduction}

Construction impacts the quality of life for building and infrastructure facilities and plays a major role in a nation's economy and development. According to Farooquiet al(2008), the construction sector is globally considered to be a basic industry on which the development of a country depends. 'Quality Assurance' and 'Quality Control' are used interchangeable when discussing the broad issue of quality in construction, as posited by Rogers (2018). However, these phrases describe very different activities, even though they work to deliver a final product that meets the project's specifications and customer's expectations.

To a great extent, the growth of a country and its development status is generally determined by the quality of its infrastructure and construction projects. According to Pun (2014), quality assurance and control is contained in the tripod of construction management; it does not only impact appearance and durability but also the performance of a project. Performance evaluation in construction projects generally focuses on a limited number of performance elements which is the act of fulfilling the project goals related to the product; which are completing the project on time, within budget and with the required quality and to client's satisfaction (Enshassiet al,2014). Nowadays, both public and private sectors place 
more emphasis on the quality assurance and control of products rather than the cost and time which was the major concern in the past (Abdul-Rahman et al, 2010).

Therefore, in order for construction clients and end users of completed facilities to realise best value, the concept of quality assurance and control must be stressed in the industry to improve the quality of product and services (Idrus and Sodangi, 2010). The willingness to change the quality culture and the commitment of top management towards quality will determine the success of quality assurance and control in the industry (Zeynepet al, 2008).

Quality and efficiency have been identified as the major imperatives lacking in Nigeria's construction industry. From a general knowledge, a number of construction firms in Nigeria under-pay their workers, with this poor salary package 'quality might never be ingrained in assurance and control'. Construction labours tend to focus more on the number of hours worked and quantity of work done rather than the quality of work executed. In regard to this, all stakeholders involved in construction projects have a role to play in order to deliver a quality product. This study sets out to assess the implementation of quality assurance and control in Abuja and its Environs within Nigeria.

\subsection{Aim of this Study}

The quality control process is an on-going one and extends to all parts of the construction projects, therefore the aim of this research is to assess the importance of quality assurance (QA) and quality control (QC) through the following objectives:

- To identify the prerequisites for QA and QC through literature

- To understand the concept of QA and QC specifications and how it applies to design process

- Administration of questionnaire to stakeholders in the construction industry on compliance and noncompliance of QA and QC.

\section{Concept of Quality Assurance and Control}

Bester field, (2003) states that quality assurance is a set of activities done before the manufacturing or planning process of products and services to assure good quality to the customers. In addition, it emphasised defect prevention by improving production and associated processes to avoid or reduce chances that might cause defects in the first place, whereas quality control is a set of activities done during manufacturing products or delivering services to customers by testing and blocking the release of defensive outputs; thus, it emphasizes defect detection.

Quality Control (QC) simply refers to the process of inspecting the product to identify and correct defects. As a tool, QC can be thought of as a corrective tool, typically carried out by a specific group of individuals on a job site (Jim Rogers 2018). This means it is part of the quality management system QMS that tests to make sure that a product or service meets the required standards. This will require decisions to be made about the type of checking required for different aspects of the project; either through inspecting, testing, measuring or analysis. The primary objectives of quality control assignments are to:

- Avoid duplication of effort

- Assure that every quality aspect is covered

- Provide a clear delineation of responsibilities

- Provide effective guidance on the project to achieve quality work

- Provide documentation of materials, installations and tests

\subsection{Requirements for Quality Control}

According to Sanjeev (2020), Quality Control process includes quality planning, training, providing clear decisions and directions, constant supervision, immediate review of completed activities for accuracy and completeness, and documenting all decisions, assumptions and recommendations. This stipulates that in the construction plan development process, the sole responsibility of the designer is to ensure all project elements are economical, accurate, properly prepared, coordinated, checked, and completed. In order for the project to consistently meet the needs and expectations of our clients and users. Quality is as important as the schedule and budget.

\subsection{Construction Quality Policies and Plans}

Construction companies may have a series of documents that deal with different aspects of quality of the work. However, the ISO 9001:2000 provides the basis for a generic quality document that outlines: a responsibility for quality, a quality policy, quality planning, a quality organisational structure, guidelines on quality and the review processes. Individual quality plans for specific construction projects will be derived from this generic one as additions will be made depending on the circumstances. Since each construction project is an entirely new experience, quality plans are developed for each one and are used throughout the project to assure quality.

The purpose of such plans is to put in place a quality control system for the project which shall set out inspection, testing, control and verification requirements for all aspects of the project. Inadvertently, the quality plan also sets out mechanism for showing how quality will be achieved. It also contains information about the key personnel. The QP is likely to be revised and updated as the project progresses and as certain changes to the scope of works arise.

\subsection{Role of ISO-9000 in Construction}

International Standard Organisation (ISO) -9000 facilitates the implementation of standards, systems, activities as and responsibilities of construction workers (Bubshait, 1999). This is important because it improves quality image of the construction industry, marketing advantage and efficiency, and reduces wastage; while it ensures customer satisfaction. 
The difference between ISO-9001 and 9002 is essentially the design based on client's requirements.ISO-9000 quality system standard describes what the requirement of quality-oriented system is as it does not set out special requirement.

\section{Research Methodology}

Quantitative research approach with descriptive design was adopted and the administration of questionnaires for the study was limited to Abuja the Federal Capital Territory of Nigeria and Environs. Professionals practicing in Abuja were covered in this study, namely: civil engineers, builders, architects, quantity surveyors, land surveyors and skilled technicians. Simple random sampling technique was employed as it is the least bias of all the sampling techniques. This technique was adopted because it is devoid of subjectivity where each member of the total population has equal chance of being selected. The study involved 19 civil engineers, 18 builders, 21 architects, 9 quantity surveyors, 3 land surveyors, and 5 skilled technicians.

Statistical analysis was executed with the assistance of the International Business Machines(IBM) and Statistical Package for the Social Sciences (SPSS) Software. This software was selected because it is well established and suitable for analysing the type of data that were collected in this study. The data collected were mainly of a nominal or categorical nature and were manipulated using various descriptive statistics such as mean, standard deviation, standard error and percentages.

\section{Results and Discussion}

\begin{tabular}{|c|c|c|c|c|c|c|c|}
\hline $\begin{array}{c}\text { Organisational } \\
\text { Compliance }\end{array}$ & NC & PC & FC & GC & TC & Mean & Rank \\
\hline $\begin{array}{c}\text { Materials Selection and } \\
\text { Usage }\end{array}$ & $0(0)$ & $0(0)$ & $2(2.7)$ & $10(13.3)$ & $63(84.0)$ & 4.81 & 1 \\
\hline $\begin{array}{c}\text { Inspection And Testing } \\
\text { of Excluded Works }\end{array}$ & $2(2.7)$ & $0(0)$ & $4(5.3)$ & $18(24.0)$ & $51(68.0)$ & 4.55 & 2 \\
\hline Use Of Code of Conduct & $0(0)$ & $1(1.33)$ & $5(6.67)$ & $57(76.00)$ & $12(16.00)$ & 4.07 & 3 \\
\hline $\begin{array}{c}\text { Report Of Non- } \\
\text { Conformity to Quality } \\
\text { Standards }\end{array}$ & $0(0)$ & $2(2.7)$ & $2(2.7)$ & $62(82.7)$ & $9(12.0)$ & 4.04 & 4 \\
\hline $\begin{array}{c}\text { Construction Process } \\
\text { Adoption }\end{array}$ & $0(0)$ & $2(2.7)$ & $0(0)$ & $66(88.0)$ & $7(9.3)$ & 4.04 & 4 \\
\hline Recording Charges & $0(0)$ & $2(2.7)$ & $52(69.2)$ & $17(22.7)$ & $4(5.3)$ & 3.31 & 6 \\
\hline
\end{tabular}

Table 1: Organisational Compliance to Quality Control Measures

NC- None Compliance, PC-Poor Compliance, FC-Fair Compliance, GC-Good Compliance, TC-Total Compliance

\subsection{Organisational Compliance to Quality Control Measures}

Table 1 illustrates the top significant variables of quality control measures and according to the perception of respondents, their organisation compliance is rated as follows: materials selection and usage has $84.0 \%$ total compliance with a mean score of 4.81, inspection and testing of excluded works with $96.0 \%$ total compliance with a mean score of 4.55 is next. Use of code of conduct had $76.0 \%$ good compliance with a mean score of 4.07, report of non-compliance and construction process adoption with mean score of 4.04 and the least was recording charges with 69.3 fair compliance with a mean score of 3.31. This apparently means that most construction organisations in Abuja show great level of compliance to the above quality control measures.

\begin{tabular}{|c|c|c|c|c|c|c|c|}
\hline Effects & NS & NSS & SS & S & VS & Mean & Rank \\
\hline Cost Overruns on Projects & - & - & $15(20)$ & $37(49.3)$ & $23(30.7)$ & 4.10 & 1 \\
\hline Untimely Project Delivery & - & - & $23(30.7)$ & $30(40.0)$ & $22(29.3)$ & 3.98 & 2 \\
\hline $\begin{array}{c}\text { Poor Infrastructural } \\
\text { Deliverables }\end{array}$ & - & $7(9.3)$ & $15(20.0)$ & $45(60.0)$ & $8(10.0)$ & 3.72 & 4 \\
\hline $\begin{array}{c}\text { Structural Failures } \\
\text { Leading to Death }\end{array}$ & - & $16(21.3)$ & $30(40.0)$ & $22(29.3)$ & $7(9.3)$ & 3.26 & 3 \\
\hline Damage To Reputation & $7(9.3)$ & $15(20.0)$ & $22(29.3)$ & $24(32.0)$ & $7(9.3)$ & 3.12 & 5 \\
\hline
\end{tabular}

Table 2: Effects of Non-Adherence to Quality Assurance and Control

Ns- Not Serious, NSS- Not So Serious, Ss-Sometimes Serious, S- Serious, Vs- Very Serious

\subsection{Effects of Non-Adherence to Quality Standards}

Table 2 shows the respondent's opinion on the effect of not adhering (compliance) to quality assurance and control standards and the most severe factor suffered by organisations for non-compliance is Cost overruns on projects with mean value of 4.10, untimely project delivery (time overruns) with mean value of 3.98 , poor infrastructure deliverables with mean value of 3.72, while structural failures leading to death with mean value of 3.26 , and damaged reputation at a mean value of 3.12 which is considered to be the least suffered. 


\begin{tabular}{|c|c|c|c|c|c|c|c|}
\hline Factor & NA & RA & SO & OF & MO & Mean & Rank \\
\hline $\begin{array}{c}\text { Incompatible Tendering } \\
\text { Procedures }\end{array}$ & - & - & - & $36(48.0)$ & $39(52.0)$ & 4.52 & 1 \\
\hline Design Complexity & - & - & - & $39(52.0)$ & $36(48.0)$ & 4.48 & 2 \\
\hline $\begin{array}{c}\text { Poor Performance of } \\
\text { Quality Assessment } \\
\text { Tools }\end{array}$ & - & - & - & $52(69.3)$ & $23(30.7)$ & 4.30 & 3 \\
\hline $\begin{array}{c}\text { Lack Of Contractor's } \\
\text { Supervision }\end{array}$ & - & - & $8(10.7)$ & $37(49.3)$ & $30(40.0)$ & 4.29 & 4 \\
\hline $\begin{array}{c}\text { Low Tendency to Team } \\
\text { Work }\end{array}$ & - & - & $16(21.3)$ & $21(28.0)$ & $38(50.7)$ & 4.29 & 4 \\
\hline $\begin{array}{c}\text { Bureaucracy } \\
\text { Low Quality Drawing } \\
\text { and Specifications }\end{array}$ & - & - & $14(18.7)$ & $31(41.3)$ & $30(40)$ & 4.21 & 6 \\
\hline Lack Of Auditing System & - & - & $16(21.3)$ & $28(37.3)$ & $31(41.3)$ & 4.20 & 7 \\
\hline $\begin{array}{c}\text { Lack Of Motivation } \\
\text { Poor Relationship and } \\
\begin{array}{c}\text { Partnering Among } \\
\text { Project Participants }\end{array}\end{array}$ & - & - & $7(9.3)$ & $46(61.3)$ & $22(29.3)$ & 4.20 & 7 \\
\hline $\begin{array}{c}\text { Low Effective Project } \\
\text { Management System }\end{array}$ & - & - & $30(40.0)$ & $30(40.0)$ & $15(20.0)$ & 3.80 & 11 \\
\hline $\begin{array}{c}\text { Difficult Data Collection } \\
\text { System }\end{array}$ & $15(20.0)$ & $38(50.7)$ & $15(20)$ & $7(9.3)$ & - & 2.81 & 12 \\
\hline $\begin{array}{c}\text { Inappropriate Method } \\
\text { of Contractor }\end{array}$ & $8(10.7)$ & $30(40.0)$ & $22(29.3)$ & $15(20.0)$ & - & 2.58 & 13 \\
\hline
\end{tabular}

Table 3: Factors Affecting Assessment of Quality Control Implementation of Construction Projects - Not At All, Ra-Rarely, So- Sometimes, of- Often, Mo- Most Often

\subsection{Factors Affecting Assessment of Quality Control Implementation of Construction Projects}

Various factors affecting the assessment of implementation of construction projects were evaluated by respondents as shown in table 3 , and each factor in the variable was considered as a barrier for assessing implementation of construction projects. Incompatible tendering procedures, design complexity, Poor performance of quality tools, Lack of contractor's supervision and Low tendency to team work at a tally as most significant factors with mean values of 4.52, 4.48, 4.30 and 4.29 respectively. Bureaucracy, Low quality drawing and specifications and Lack of auditing system at a tally with mean values of 4.21 and 4.20. Lack of motivation, Poor relationship and partnering among project participants and Low effective project management system with mean values of 4.08, 4.02 and 3.80. Least significant factors are difficult data collection system and inappropriate method of contractor with mean values 2.81 and 2.58 .

\begin{tabular}{|c|c|c|c|c|c|c|c|}
\hline $\begin{array}{c}\text { Benefits Of Quality } \\
\text { Assurance \& Control }\end{array}$ & NE & RA & SO & OF & AL & Mean & Rank \\
\hline Improved Site Management & - & $8(11.59)$ & $30(43.48)$ & $25(36.23)$ & $6(8.70)$ & 3.29 & 1 \\
\hline $\begin{array}{c}\text { Enhanced Reputation for Good } \\
\text { Design and Construction for } \\
\text { Contractors }\end{array}$ & - & $4(5.63)$ & $38(53.52)$ & $26(36.62)$ & $3(4.23)$ & 3.23 & 2 \\
\hline More Effective Planning & $2(2.74)$ & $10(13.70)$ & $21(28.77)$ & $31(42.47)$ & $9(12.33)$ & 3.20 & 3 \\
\hline $\begin{array}{c}\text { Provision Of Feedback for Use } \\
\text { in Future Projects }\end{array}$ & - & $13(17.81)$ & $39(53.42)$ & $19(26.03)$ & $2(2.74)$ & 3.18 & 4 \\
\hline $\begin{array}{c}\text { Fewer Delays of Projects and } \\
\text { Disruption }\end{array}$ & - & $12(16.44)$ & $32(43.84)$ & $23(31.51)$ & $6(8.22)$ & 3.06 & 5 \\
\hline $\begin{array}{c}\text { Lower Cost of Remedial and } \\
\text { Repeat Works }\end{array}$ & - & $6(8.22)$ & $37(50.68)$ & $28(38.36)$ & $2(2.74)$ & 3.04 & 6 \\
\hline Production Of Better Designs & - & $4(5.48)$ & $48(65.75)$ & $17(23.29)$ & $4(5.48)$ & 3.01 & 7 \\
\hline $\begin{array}{c}\text { Efficient Management of } \\
\text { Construction Projects }\end{array}$ & $2(2.74)$ & $10(13.70)$ & $27(36.99)$ & $29(39.73)$ & $5(6.85)$ & 2.87 & 8 \\
\hline
\end{tabular}

Table 4: Benefits Derived From the Application of Quality Assurance and Control to Project Delivery

$$
\mathrm{Ne} \text {-Never Ra-Rarely So-Sometimes Of-Often Al-Always }
$$

\subsection{Benefits Derived from the Application of Quality Assurance and Control to Project Delivery}

Based on the benefits to be derived from the application of quality standard to project delivery as illustrated in the table 4 above, significant among the benefits are improved site management and Enhanced reputation for good design and construction for contractors with mean values of 3.29 and 3.23. More effective planning and Provision of feedback for use in future projects are next most significant with mean values of 3.20 and 3.18. Fewer delays of projects and disruption and Lower cost of remedial and repeat works with mean values of 3.06 and 3.04. Least significant of the benefits are 
Production of better designs and Efficient management of construction projects with mean values of 3.01 and 2.87 respectively.

\section{Conclusion}

From the findings, the study concludes that ensuring quality assurance and control in project deliverables is firmly dependent upon enforcement of quality standard and the need for clients to know and communicate their specific needs to the consultant/designer who accurately represents it, on to the contractor faithfully reproducing the requirements on site and finally the end-user using the building correctly. Quality assurance practice should not be limited to some specific persons as it is a concern of all if it is to be effective. Furthermore, without effective enforcement by government agency and/or regulatory bodies and clients demanding thorough proof of contractors' credentials for quality assurance capability before compiling their tender lists, a gap will continue to exist between the level of awareness and the quality of project deliverables in the country.

The quality control process should also include a system for dealing with problems as they are. For instance, if an error is found on a drawing, decisions will need to made about what to do with the drawing, who needs to be notified when it needs to be reproduced and who needs to do the rechecking; during the construction phase, materials found not to meet the standard required should be removed from the site so that they do not contaminate material that does meet the standard; common mistakes made by suppliers include sending the wrong batch or damaging material in transit. If the problem stems from poor workmanship, the work will often have to be redone; identification of problems and dealing with these problems is part of the quality control process and the cost of rework can be very high. Builders should therefore try to minimize mistakes so that they do not have to bear the cost. Reworking drawings, replacing materials, and disposing of waste cost time and money and such errors need to be minimized as much as possible.

Finally, the findings have revealed that the implementation of quality management can be affected mostly on customer's satisfaction, followed by cost, and time respectively.

\section{Recommendations}

- Design personnel shall follow established design policies, procedures, standards and guidelines in the preparation and review of all design products.

- Design consultants are agents for the project with the primary responsibility for preparation of construction plans. Consultants must ensure quality and adhere strictly to established design policies.

- Construction companies should register with Standard Organization of Nigeria (SON) so as to keep them abreast of the new trends of minimum standards for quality assurance and control in the construction industry.

\section{References}

i. Abdul Rahim, H., Mohd Zaimi, A. M., Bachan, S., Wan Zulkifli W. Y., \& Mohd Sofiyuddin A. S. (2010). Perlaksanaansistempengurusankualiti ISO 9000 dalamindustripembinaan. Proceeding of the 4th Micra Conference. Kuala Lumpur: University of Malaysia.

ii. Abdulaziz A. Bubshait, Member, ASCE,' ISO 9000 Quality', Standards in Construction' Journal of Management in Engineering / November/December 1999

iii. Brown, A., Van der Wiele, T., \& Loughton, K. (1998). Smaller enterprises experiences with ISO 9000. International Journal of Quality and Reliability Management, 15(3), 273-85.

iv. Enshassi, A., Arain, F. \& El-Rayyes, Y. (2014). Post-evaluation system in construction projects in Gaza StripPalestine. Journal of Construction in Developing Countries, 19(2), 51-73.

v. Farooqui, R.U., Masood, R., \& Aziz, J. (2008). Assessing the viability of total quality management implementation in contracting firms of Pakistani construction industry, ICCIDC-I 'Advancing and Integrating Construction Education, Research \& Practice.

vi. Pun, K.F. (2014). Post-Conference Report: The Third Industrial Engineering and Management (IEM3-2014) Conference, the Faculty of Engineering, University of the West Indies, St. Augustine.

vii. Sanders, D. \&Hild, C. (2000). A discussion of strategies for six sigma implementation. Quality Engineering, 12 (3), 303-309.

viii. Santos, L. \&Escanciano, C. (2002). Benefits of the ISO 9000:1994 system. The International Journal of Quality and Reliability Management, 19 (3), 321-344

ix. Wong, A. (2009). Total Quality Management in the Construction Industry in Hong Kong: A supply chain management perspective, Total Quality management, 10, (2), 199-208. 